\title{
The Prologue and Ralph Ellison's Existentialist Philosophical Concept About Black People Invisibility in Invisible Man
}

\author{
Beugre Zouankouan Stéphane \\ University of Pelefero Gon Coulibaly, Côte d'Ivoire
}

Doi: 10.19044/llc.v7no3a1 URL:http://dx.doi.org/10.19044/llc.v7no3a1

\begin{abstract}
This paper aims to study the existentialist philosophical concept developed by Ralph Ellison in the prologue of his novel INVISIBLE MAN and which characterizes black people invisibility and existence since long time. It also analyzes how this philosophical concept sustains and permeates the overall relationships between white people and black people in the white American society and at large, in today's blacks and whites relationships. Indeed when transcending the surface meaning of the prologue of the novel, one can realize with a thorough reading of the notion of invisibility that Ralph Ellison develops an existentialist philosophical concept about black people invisibility and existence which is quite different from the well known existentialist concept about human beings existence developed long time ago by the French philosopher René Descartes. In a metaphorical and symbolic language and with an ironic description of black Americans' reality, he reveals the reasons why black people are invisible in the white American society and by the same way, he reveals the philosophical concept sustaining or linked to black people invisibility. Finally, one can observe how two existentialist philosophical concepts are opposed in scrutinizing closely the notion of invisibility developed in the prologue of INVISIBLE MAN.
\end{abstract}

Keywords: American society, black people Invisibility, Existentialist Philosophical Concept, blacks and white's relationships, "I AM", "I might even be said to possess a mind. 


\section{Introduction}

Beginning with the sentence "I AM an invisible man" (Ellison, 1952:7), the notion of "Invisibility" is one of the major themes developed in the prologue ${ }^{1}$ of the novel INVISIBLE MAN ${ }^{2}$. Through this motif, Ralph Ellison evokes the question of African-Americans existence in the white American society and at large, he evokes the question of black people existence in a world controlled and dominated by white people. Indeed, the problem of African-Americans existence and the problem of black people existence is their invisibility in a world controlled and dominated by white people. The perception that white people have about black people due to black people's "blackness" creates a real, constant and topical problem of invisibility for black people in the society. Such a perception and the invisibility constructed create as a result a real topical problem of existence for black people as revealed by Ralph Ellison in this novel.

[T] he Negro is a sort of seventh son, born with a veil, and gifted with second-sight in this American world, a world which yields him no true selfconsciousness, but only lets him see himself through the revelation of the other world. It is a peculiar sensation, this double-consciousness, this sense of always looking at one's self through the eyes of others, of measuring one's soul by the tape of a world that looks on in amused contempt and pity. One ever feels his twoness, - an American, a Negro; two souls, two thoughts, two unreconciled strivings; two warring ideals in one dark body, whose dogged strength alone keeps it from being torn asunder. (Lyne, 1992:319)

In fact, people may observe in Ralph Ellison's INVISIBLE MAN that the motif of invisibility is not only a very important one among many others but it is central ${ }^{3}$ to the novel. This notion is central to the novel because first of all the word "invisible" is part of the title 4 . Secondly, the word "invisible" is part of the name of the protagonist "Invisible Man". Thirdly, the word

1 The Prologue set at the end of the action introduces most of the major themes and images and it also, as a lucid introduction, starts open the notion of invisibility and introduces us with this notion of invisibility which involved many images and dualities such as light/darkness, light/power, image of electricity, etc.

2 The title of the novel will be written in this style in this paper so that we can make a difference between it and the name of the protagonist-narrator and major character which is also "Invisible Man".

3 This notion is central simply because the words "invisible", "invisibility", and the expressions "I am an invisible man", "I am invisible", "my invisibility", "invisible man", "that invisibility", "an invisible man" appear several times in the prologue and control the sense and orientation of the narration in the prologue.

4 The title of the novel is INVISIBLE MAN so since the title of the novel, the author tries to focus our attention and reflection on this relevant notion of invisibility that he deals with.

5 "Invisible Man" is the name of the protagonist-narrator and the major character in the novel INVISIBLE MAN. So all the actions related to the major character are involved with the notion of invisibility that surrounds the entire novel as the main character evolves. 
"invisibility" is the main concern at the beginning of the novel through the "prologue" $"$ and its first sentence "I AM an invisible man", as a fundamental sentence. And fourthly, there are several metaphorical and symbolical meanings linked to the expression "Invisible Man" both in the title of the novel and in the name of the main character.

You might think of the Prologue as a personal introduction. "I am an invisible man," is the first sentence of the novel. It establishes immediately the fact that this is to be a first-person narrative and that the theme of invisibilitywhich gives the novel its title- is extremely important. The nameless narrator explains that this invisibility is not literal but metaphorical or symbolic. (Abbott, 1985: 51)

This focus and insistence made by the author on the motif of invisibility with all its metaphorical and symbolical aspects oblige the readers to go beyond the word "Invisible", the expression "Invisible Man", and the notion of "Invisibility" itself to deal with the "hidden" existentialist philosophical concept linked to the theme of invisibility surrounding the novel.

To be concise and precise, through the key terms "Invisible", "Invisible Man", and "Invisibility", Ralph Ellison develops metaphorically a philosophical concept of existence ${ }^{7}$ linked to African-Americans in the United States of America and at a larger point, a philosophical concept of existence linked to all black people through the character of "Invisible Man". One may also observe that this philosophical concept developed by Ralph Ellison at least is in contrast or contradictory to the philosophical concept of existence developed normally in favor of any human being existence by René Descartes ${ }^{8}$.

Indeed, the philosophical concept of existence developed metaphorically by Ellison is seen through the combination of the words in the expression "Invisible Man" or is better seen when confronting the two words "Invisible" and "Man", both in the title of the novel and in the name of the protagonist ${ }^{9}$. Because there is automatically a kind of nonsense which arouses and then begins our misunderstanding ${ }^{10}$ of such juxtaposition of words or

\footnotetext{
6 This particular novel is divided in parts as follow: a prologue, 25 chapters and an epilogue, a kind of division which focuses our attention on the prologue as a major constituent of the novel and an important one.

7 "Call me, since I have a theory and a concept, a "thinker-tinker."” in INVISIBLE MAN, p.10. 8 The thesis developed by René Descartes in Discourse on the Method (1637): when stating: "je pense donc je suis" (I think, therefore I am).

9 Both the novel and the protagonist share the same "name" (name considered as the title of the novel and name considered as the name of the major character).

10 A failure to understand or interpret something correctly and in this case it is the expression "Invisible Man".
} 
contradiction of meanings thanks to the metaphor and symbolism used by the author in the expression "Invisible Man".

That is why the central problematic in this paper is therefore to know how black people invisibility betrays a new existentialist philosophical concept which is developed metaphorically by Ralph Ellison in the prologue of his novel. This central problematic in order to be solved will revolve around two important questions that will constitute the blueprint of this analysis.

First of all, what is the existentialist philosophical concept about any human being existence developed by Descartes and how it functions to be in contradiction with the notion of black people invisibility developed in the prologue?

Secondly, what is the new existentialist philosophical concept linked to black people invisibility and existence and developed metaphorically by Ralph Ellison and also how it functions to be in contradiction with black people visibility or again how it functions to be against black people visibility?

The theoretical background that will be used in responding to those questions related to black people invisibility will be theories such as African American criticism, Stylistics and as approach; it will be a hermeneutics analysis or the critical interpretation of the prologue of the novel INVISIBLE MAN.

Still, in terms of theoretical background, it is important to precise that stylistics is really important here because Ralph Ellison in the prologue uses metaphors, irony, symbols, images and contradiction, and also a specific typography to describe black people invisibility. African American criticism is useful in this study because of race relations, racism, also because of the first concerned who are African-Americans through their invisibility and experience. And also due to the fact that Ellison places the notion of black people invisibility first in the American society and namely in blacks and whites relationships.

This study will revolve around three parts. It is important first of all to talk about the presence of philosophical concepts in the notion of invisibility in Ralph Ellison's INVISIBLE MAN. Secondly, it will be useful to present and study Descartes' existentialist philosophical concept and show how it reinforces the reflection made by Ellison about black people invisibility. The last part will present and analyze Ralph Ellison's metaphorical existentialist philosophical concept about black people invisibility. 


\section{Philosophical Concepts in The Notion of Invisibility in Ralph Ellison's Invisible Man}

Considered as the real conclusion of this novel, one may observe through a thorough analysis that the prologue introduces us to a very fundamental philosophical concept about black people existence and namely about black Americans existence as well as it also does for other blacks' fundamental instructions and information ${ }^{11}$ about their lives in white America. Indeed, in a very ironic ${ }^{12}$, metaphorical ${ }^{13}$, and symbolic ${ }^{14}$ way, the prologue develops in a brief but relevant thesis ("I AM an invisible man") a notion of invisibility linked to the protagonist-narrator (major character) of the novel who is a black man. The invisibility which characterizes the major character is due in fact to his "blackness" as a black man and to the perception that white people have about him due to this "blackness". In accordance with such invisibility, he identifies himself henceforth as "Invisible Man ${ }^{15}$ and therefore this name reinforces symbolically the meaning and suitability of the title of the novel as clarified here by Harold Bloom (2008: 19-64):

The Invisible Man is the rhetorically flamboyant unnamed narrator of Ellison's novel. He is invisible not because he is a "spook"-literally unseen - but because he is a black man living in the racist atmosphere of America in the 1920s and 1930s, unrecognized because of his skin color...In the Prologue to Ralph Ellison's Invisible Man, the narrator explicates the novel's central metaphor by telling us that he is invisible because "[white] people refuse to see [him]." The narrator proceeds to illustrate this assertion with a story about a violent confrontation that took place between himself and a white man.

In fact, set up in the context of the American society, one realizes that this notion of invisibility linked to "Invisible Man", not only foreshadows the relationships between white people and black people in terms of superiority and inferiority. But moreover, it really describes, denounces the existentialist philosophical concept which characterizes the major character who is a black man and, by the same way reveals the existentialist philosophical concept

11 As an example we may refer to the passage about music (Blues) and its importance for black people: "when I have music I want to feel its vibration, not only with my ear but with my whole body. I'd like to hear five recordings of Louis Armstrong playing and singing "What Did I Do to Be so Black and Blue" -- all at the same time." in INVISIBLE MAN, pp.10-11.

12 The story of his encounter with a man one night: "One night I accidentally bumped into a man, and perhaps because of the near darkness he saw me and called me an insulting name ... a man almost killed by a phantom".

13 The main metaphor of his invisibility resides in the sentence "I AM an invisible man". 14 Many symbols pertain the prologue (invisibility, visibility, light, darkness, blackness, power etc.)

15 "Invisible Man" is the name of the protagonist and the major character in the novel INVISIBLE MAN. 
which characterizes all the black people around the world. Indeed, what defines INVISIBLE MAN as an existentialist novel, Cevik (2012:6) maintains "is how Ellison narrates his protagonist's life experiences at which point the narrator realizes that he must assert an identity".

Invisible Man by Ralph Ellison introduces the major themes that define the novel. The motifs of invisibility and blindness allow for an examination of the effects of racism on the victim and the perpetrator. The novel also places itself within larger literary and philosophical contexts. Especially apparent is the influence of existentialism. At the time of Invisible Man's publication in 1952, existentialism had reached the height of its popularity; Ellison's book proposes to undertake a similar examination of the meaning of individual existence, but through the lens of race relations in postwar America. (Cevik, 2012:5)

To go further in our explanation, the perception that white people have about black people in the society creates a kind of invisibility of black people and such a perception with the invisibility resulting permit us to detect the philosophical concept of black people existence which is metaphorically stated by Ellison. It is quite clear that this new and other existentialist philosophical concept, theory or thesis is opposed to that of René Descartes which normally should apply to any human being. And it appears clearly that the distance between superior white and inferior black is quite explicit when we compare the two theses because we realize at last (thanks to the perception that white people have about black people) that they (white people) are defined by their own existential philosophical concept which is different from that defining black people existence; the one revealed metaphorically in the prologue by Ralph Ellison.

"I am an invisible man," he tells you in the first sentence of the novel. When he calls himself invisible, he means that other people don't see him, that no one recognizes him as a person, as an individual. A helpful way to understand the Invisible Man as a character is to use the ideas of the noted twentieth-century Jewish philosopher, Martin Buber. Buber distinguishes between I-Thou relationships and I-It relationships. When we love someone, there is an I-Thou relationship, one between two individuals who truly care for one another as persons. In an I-It relationship we use others as things. We like people for what we can get out of them. If you apply this idea to Ellison's central character, you may conclude that he is invisible because people always see him as an "It," never as a "Thou." (Abbott, 1985:21)

By developing the problem of African-Americans invisibility and existence in the white American society, and concerning the context of this study (the prologue), Ralph Ellison, as a visionary writer, has revealed a new fundamental existentialist philosophical concept related to black people 
themselves and to their existence in the world due to the fact that their "blackness" creates their invisibility.

James is most concerned with the rarefied aesthetic task of endowing the coarse material of life with "the high attributes of a Subject" (48), while Ellison works with the more socially and ideologically saturated contradiction of the disregarded African American's "high visibility". (Lyne, 1992: 323)

In the first point, we will study how generally speaking human being (and namely in this context a white man) is considered to have a true existence and a visibility referring to Descartes' existentialist philosophical concept. And in the second point, we will study how especially black people and a black man (here the protagonist-narrator) is seen or considered most of the time to be inexistent ${ }^{16}$ and to be invisible by analyzing Ellison's metaphorical existentialist philosophical concept.

\section{Descartes' Existentialist Philosophical Concept Which Reinforces the Notion of Black People Invisibility Developed by Ralph Ellison}

The phrase je pense, donc je suis, usually translated into English as "I think, therefore I am" and in Latin as Cogito ergo sum, originally appeared (in French) in Descartes' Discourse on the Method (1637) in the first paragraph of its fourth part:

Mais aussitôt après je pris garde que, pendant que je voulais ainsi penser que tout était faux, il fallait nécessairement que moi qui le pensais fusse quelque chose; Et remarquant que cette vérité, je pense, donc je suis, était si ferme et si assurée, que toutes les plus extravagantes suppositions des Sceptiques n'étaient pas capables de l'ébranler, je jugeai que je pouvais la recevoir sans scrupule pour le premier principe de la Philosophie que je cherchais.

(translation into English) But immediately upon this I observed that, whilst I thus wished to think that all was false, it was absolutely necessary that I, who thus thought, should be something; And as I observed that this truth, I think, therefore I am, was so certain and of such evidence that no ground of doubt, however extravagant, could be alleged by the Sceptics capable of shaking it, I concluded that I might, without scruple, accept it as the first principle of the philosophy of which I was in search.

When one considers the thesis "I think, therefore I am" stated by the French philosopher René Descartes, one may observe and state that any human being is characterized by such a philosophical concept of existence. And this philosophical concept of existence "I think, therefore I am" in its first aspect

16 Or to be denied a true existence or to live in "a country which treats him as a non-being" https://www.penguin.co.uk/books/256/25629/invisible-man/9780241970560.html consulted on January 10th, 2020. 
"I think"17 illustrates and classifies quite clearly any human being as first a person of thinking, a person of consciousness, a person of brain, a person of mind and a person of reason or rationality. Then, in its second aspect "I am"18, this philosophical concept of existence illustrates and classifies quite clearly any human being later or after as a person being or a person existing ${ }^{19}$ (or a person in existence) through the body, the flesh, the blood, the physical existence and the presence "in the real world" 20.

René Descartes (1596-1650) was a French philosopher and mathematician, credited as a foundational thinker in the development of Western notions of reason and science. His philosophy was built on the idea of radical doubt, in which nothing that is perceived or sensed is necessarily true. The only thing that remains true that there is a mind or consciousness doing the doubting and believing its perceptions, hence the famous formulation, 'I think therefore I am', or in Latin, the cogito'Cogito ergo sum'. Descartes also proposed that the mind and body were two separate and distinct entities, but even the body was not so certain a thing as the mind, because, like everything else in the world, the body could only be sensed because there was a mind to sense it. In 1663, Descartes' writings were placed on a list of prohibited books by the Pope, because of the central place Descartes gave to reason and mind, rather than God, in his philosophy. ${ }^{21}$

So the relationship between those two distinct entities "I think" and "I am" established by the connecting word "therefore" 22 due (first) to its meaning and (then) to its contextual role between those two entities ("I think" and "I am") is not simple. This relationship shows clearly that the fact to think (cogitate) comes first and the fact to be or to exist comes later (or after) as far as human beings are concerned. It also shows clearly that the fact to think justifies the fact to be (exist) because it (this adverb) correlates them (the two

17 "I think" means first I am characterized by my cogitation, my capacity of reflection, my thinking, my consciousness, my brain.

18 "I am" means first I exist as human being, I am a body, I am a flesh.

19 The phrase "I think, therefore I am" first appears in Discourse on the Method (1637). But Descartes changes the wording to "I am, I exist" in his most famous (1641) work, Meditations on First Philosophy (called the Meditations for short). https://1000wordphilosophy.com/2018/11/26/descartes-i-think-therefore-i-am/ consulted on January 10th, 2020.

20 Ralph Ellison, INVISIBLE MAN, Penguin Modern Classics, USA, 1952, p. 7.

21 https://newlearningonline.com/new-learning/chapter-7/descartes-i-think-therefore-i-am consulted on January 10th, 2020.

22An adverb meaning: and so, or because of that --- accordingly, or to that purpose ---Therefore and thus are both fairly formal words that introduce a statement that is a consequence of the previous statement. They should not be used as empty connectors when what follows them does not derive from what precedes them. Microsoft ${ }^{\circledR}$ Encarta ${ }^{\circledR} 2009$. $(C$ 1993-2008 Microsoft Corporation. Tous droits réservés. 
entities "I think" and "I am") as a cause and effect relationship ${ }^{23}$ : "I think" [because of that] "I am".

and as I observed that this truth, I think, therefore I am (cogito ergo sum), was so certain and ... I thence concluded that I was a substance whose whole essence or nature consists only in thinking, and which, that it may exist, has need of no place, nor is dependent on any material thing; so that ' $\mathrm{I}$ ', that is to say, the mind by which I am what I am, is wholly distinct from the body, and is even more easily known than the latter ...I considered myself as having a face, hands, arms, and all that system of members composed on bones and flesh as seen in a corpse which I designated by the name of body ... ${ }^{24}$

According to the thesis "I think, therefore I am", the first important aspect of any human being is to "think" first, meaning the first visible ("easily known") thing or aspect in any human being is "thinking". The faculty of being able to use one's mind, brain, consciousness characterizes oneself as human being first: "and as I observed that this truth, I think, therefore I am (cogito ergo sum), was so certain and ... I thence concluded that I was a substance whose whole essence or nature consists only in thinking". Then the faculty of "to be" or "to exist" in the expression "I am" characterizes oneself as human being as an object (body, flesh, physical aspect) "I am a man of substance, of flesh and bone, fiber and liquids" (Ellison, 1952:7)

\section{THINK $\longrightarrow$ THEREFORE $\square$ I AM}

Another analysis that people can draw from such a thesis is that if [I don't think], it means that [I am not]: [I don't think therefore I am not] because if "I am", it is because "I think" first. So if I think, I am and if I don't think, I am not. And if I am not because I don't think, it means that I cannot be "seen", I cannot be "visible", I will be "unseen" for thanks to this thesis ${ }^{25}$ we realize that my "thinking" (brain, mind, consciousness, reason) as human being is prior and more visible than my "being" (existence or physical existence) as human being (body, flesh, physical aspect):

... I thence concluded that I was a substance whose whole essence or nature consists only in thinking, and which, that it may exist, has need of no place, nor is dependent on any material thing; so that ' $I$ ',

23 "So, the "I think" element in the Cogito implies the direct, immediate, certain knowledge of one's own existence. Thought requires a thinker and this is known with certainty." https://1000wordphilosophy.com/2018/11/26/descartes-i-think-therefore-i-am/ consulted on January 10th, 2020.

24 https://newlearningonline.com/new-learning/chapter-7/descartes-i-think-therefore-i-am consulted on January 10th, 2020.

25 "I think, therefore I am". 
that is to say, the mind by which I am what I am, is wholly distinct from the body, and is even more easily known than the latter

So through the thesis "I THINK, THEREFORE I AM", we have in terms of cause and effect relationship the following reflections:

1- FIRST TO THINK----THEREFORE----TO BE

2- FIRST TO THINK---- THEREFORE ----TO EXIST

3- FIRST SHOULD THINK----THEN---- WILL BE

4- FIRST SHOULD THINK----THEN----WILL EXIST

The result is the following equations that the cause and effect relationship may give us:

5- IF I THINK I AM------- IF I DON'T THINK I AM NOT

6- IF I THINK I EXIST-------IF I DON'T THINK I DON'T EXIST

Through these different relationships between the two components or entities of the thesis "I think, therefore I am" we may observe that the link between "I think" and "I am" is not a simple one because the other analysis possible and reliable is that if "I don't think" therefore "I am not". The relationship between these two entities is therefore so intrinsic, so reliable that you may not say "I am therefore I think" in displacement or in replacement of "I think, therefore I am" because the contextual link and meaning even the logical consequence between them (the two components or entities) are involved not as a literary play ${ }^{26}$. That is why the contrary "I am therefore I think" is not possible so one cannot say "I am therefore I think" in displacement of "I think, therefore I am".

In conclusion, I exist; I am; because I think first and my physical existence (body, flesh, blood, vein, substance or everything you may conceive as body) is proved and determined only by my brain, my mind that is why the two following theses "I think, therefore I am" and "I don't think therefore I am not" are clearly justified. The first being the product of the second, the second being the result and logical consequence of the first one.

\section{Ralph Ellison's Metaphorical Existentialist Philosophical Concept About Black People Invisibility and Existence}

In the prologue at the first paragraph, the author deals with the philosophical concept of existence of the protagonist-narrator an AfricanAmerican (or a black man) related to the notion of invisibility through the metaphorical sentence "I AM an invisible man" (Ellison, 1952:7). And we may observe that this philosophical concept of existence of black people that he develops is quite different from that of any human being existence drawn from Descartes' perspective developed above. 
Indeed, the basic contrast between the philosophical concept of existence of any human being (namely white people) and the philosophical concept of existence of black people and namely his major character resides in the fact that while for Descartes the "whole essence or nature" of any human being "consists only in thinking" ("... I thence concluded that I was a substance whose whole essence or nature consists only in thinking,") so that he may say "I think, therefore I am". Ellison presents bluntly the existentialist philosophical concept which characterizes black people both through the metaphorical sentence "I AM an invisible man" (Ellison, 1952:7) and the ironic sentence "- and I might even be said to possess a mind"27 resulting in the following complete sentence: "I AM an invisible man- and I might even be said to possess a mind". These two rhetorically flamboyant sentences through the use of metaphor and irony are the best way for Ellison to better identify and characterize black people and namely the protagonistnarrator in this racist environment because beyond showing:

that story is an integral part of the African American and Native American rhetorical traditions as they are depicted in Ellison's and Momaday's novels ... these novels also move beyond the depiction of rhetorical action to consider the relationship between rhetoric and culture, and in particular the relationship between repressed and dominant rhetorical traditions, an issue pursued by a number of contemporary rhetoricians. (Dadey, 2006: 4-5)

Through such a theory or concept "I AM an invisible man- and I might even be said to possess a mind", and through especially such rhetorical devices involved in the construction of the theory, he is proposing the end (second component) of Descartes' concept "I am" as the beginning or opening of his theory or concept. And later, he is proposing the core/fundamental interest (first component) of Descartes' concept which is "I think" to the judgment or appreciation of other persons; and also as the end and second component of his theory or concept.

The end of Descartes' concept "I am" is therefore the beginning/opening of Ellison's concept "I AM" and the beginning/opening of Descartes' concept "I think" is therefore the end of Ellison's concept "- and I might even be said to possess a mind" but here stipulated in a metaphorical and ironic way and that is the most striking aspect in his theory because Bruce Dadey (2006: 6) maintains that:

Glenn, Asante, and Berlin all propose that a system of rhetoric seems to be a neutral, catalytic medium for ideological action only from within the social or political system that produces it. When alternative systems of

27 "I am a man of substance, of flesh and bone, fiber and liquids -- and I might even be said to possess a mind." in INVISIBLE MAN, first paragraph, p 7. 
rhetoric, whose patterns of expression reflect other conceptions of social or political relations (or of the relationship between language and reality), clash with the dominant system of rhetoric, the status of rhetoric as "always already ideological" becomes apparent, and rhetoric itself becomes a site through which social struggles are enacted.

And to begin with, the fact to write the first aspect of Descartes' concept which is the "whole essence or nature" of human being in an ironic way ("- and I might even be said to possess a mind") is not a joke on the part of Ellison for it is here that resides exactly the existentialist philosophical concept related to the notion of invisibility which characterizes black people existence. Descartes' existentialist philosophical concept which should normally be attributed to any human being is "I think, therefore I am". Ellison's existentialist philosophical concept about his major character (or black people) invisibility and existence is "I AM an invisible man -and I might even be said to possess a mind" which synthetically gives the theory: "I AMand I might even be said to possess a mind".

In clear, Ellison's existentialist philosophical concept about black people invisibility and existence is stipulated such a way simply because according to Yildiray Cevik (2012:13) "the predominant white society ignores the individuality and humanity of the blacks and views them as stereotypes of slaves. As a result of this approach, the blacks are exploited and their needs are disregarded rendering them down to invisibility in a 'blind' society."

The motif of invisibility treats a black man's situation in the United States. For a long time an Afro-American's individuality was ignored by the society, and the narrator in Invisible Man faces the same problem. For centuries blacks were oppressed by the whites and treated as inferior creatures, a cheap workforce, and 'a flock of invisible people' (Juozapaityte, 2001). AfroAmericans were considered as people of lower social and intellectual status: they were not allowed the same possibilities as the white people, like receiving education, participating in public events, even deciding upon their future. They were simply deprived of their individuality (Juozapaitytè, 2001). ${ }^{28}$

In terms of style, typography or form, Ellison uses capital letters (or capitalization) for the expression "I AM" of his major character and normal letters (small) for the expression "an invisible man". A way of writing (style) which sheds a strong and excessive emphasis on the expression "I AM" of his character, an expression which is both physically (appearance and different from the other words) and typographically (capital letters) remarkable than the expression "- and I might even be said to possess a mind". The fact to use this

28 Yildiray Cevik, "The Motifs of Blindness and Invisibility within the Influence of Postwar Existentialism as Reflected in Invisible Man by Ralph Ellison" Athens: ATINER'S Conference Paper Series, No: LIT2012-0278. (2012), p. 8. 
literary form ${ }^{29}$ (capital letters) to say: "I AM" 30 in "I AM an invisible man" at the beginning of the prologue, is a way for the author to shed light on the basic contrast between the philosophical concept of existence of any human being ${ }^{31}$ and the philosophical concept of existence characterizing the protagonistnarrator, the African-Americans and black people in general because they have black skin color.

The White writer has invented and perpetuated a stereotype of the African which depicted him as physically unattractive, intellectually incompetent and spiritually degraded. Africans, according to the Whites are barbarians, born slaves, great singers, loyal servants, hard workers and true Christians. Only very low and inferior roles are assigned to the Blacks. The African is considered to be a conglomeration of mere arms and limbs, bones and eyes and as meaningless as his forests, rivers and silence. ${ }^{32}$

Indeed, while for Descartes the "whole essence or nature" of any human being "consists only in thinking", here the major character is not sure he "thinks" and he tells it clearly "- and I might even be said to possess a mind". But he is sure that he exists when he says "I AM" and he even uses capital letters to affirm this existence in the sentence "I AM an invisible man". Whereas for Descartes the expression and entity "I am" is a "latter" thing and less visible than the expression and entity "I think" ("so that 'I', that is to say, the mind by which I am what I am, is wholly distinct from the body, and is even more easily known than the latter"). The major character presents his "I AM" as the most visible thing using in terms of style, typography and form some capital letters to show it. Because for the protagonist-narrator, it is the first thing he is sure of, and the way he affirms this aspect (capital letters) is very clear both in the form and in the content.

People better understand the use of capital letters "I AM" here in "I AM an invisible man" because both in the form and in the content, Ralph Ellison wants to tell us that the "whole essence or nature" of his major character "Invisible Man" resides in his being, in his existence, in his physical existence "I AM" which consists only in "a man of substance, of flesh and bone, fiber and liquids".

$\mathrm{He}$ is invisible, he tells you, because people don't see him. They see only "my surroundings, themselves, or figments of their imagination." One reason for this is racial. The narrator is a black man, invisible because white people in America refuse to see black people as human beings, as individuals

29 Looking at the larger form and appearance of printed words on the page through capitalization.

30 Those capital letters "I AM" are quite visible than the smaller letters "an invisible man".

31 "I think, therefore I am" as stated and developed by René Descartes.

32 https://shodhganga.inflibnet.ac.in/bitstream/10603/64079/7/07_chapter\%201.pdf /

CHAPTER ONE / ASSERTIVE BLACK POETS/ consulted on January 10th, 2020. 
(Abbott, 1985:51)...The most natural theme to begin with is that of invisibility. What is an invisible man? How is the kind of invisibility Ellison writes about different from the physical invisibility of the English writer H. G. Wells' famous book The Invisible Man? A reading of Ellison's novel suggests that the theme of invisibility has different dimensions: (a) Invisibility suggests the unwillingness of others to see the individual as a person. The narrator is invisible because people see in him only what they want to see, not what he really is. Invisibility, in this sense, has a strong sense of racial prejudice. White people often do not see black people as individual human beings. (Abbott, 1985: 45)

Due to the fact that he is only sure of this physical aspect (the aspect of being or being existent), he insists on this aspect even using capitalization to affirm this existence and due to the fact that he is not sure of the other aspect "I think", he lets other persons (white people) determine whether he thinks or not "- and I might even be said to possess a mind".

In fact, the larger form of the letters used in "I AM" is quite meaningful and has a meaning that reinforces the meaning of the sentence "I AM an invisible man" as opposed to the sentence "I think, therefore I am". Through the larger form and the meaning of the letters "I AM", it is clear that the major character exists or does exist and moreover, he is so sure of his existence that he uses a literary style (capital letters) which is the larger form of the letters "I AM", as the meaningful image of his physical existence. This larger form "I AM" is also a metaphorical and symbolical aspect and representation of his existence in terms of physical existence because the shape of "I AM" is constructed in a way that anyone cannot deny his existence. ${ }^{33}$

As well as in his words and in his way of writing, the protagonistnarrator is sure of something "I AM an invisible man" and the larger form of the letters "I AM" is in fact a meaningful image of his physical existence (or physical aspect) meaning: "I am a man of substance, of flesh and bone, fiber and liquids." (Ellison, 1952:7) This physical aspect is only related to the form, to the shape; a merely physical existence like the larger form of the letter "I AM" avoids confusion and comparison to "spook", "ghost" or "Hollywood movie ectoplasms" (Ellison, 1952:7): "I AM an invisible man. No, I am not a spook like those who haunted Edgar Allan Poe; nor am I one of your Hollywood-movie ectoplasms. I am a man of substance, of flesh and bone, fiber and liquids" (Ellison, 1952:7)

33 It is put in capital letters at the beginning of the novel in a way that anyone can see it, and can observe the difference of form between the letters concerned: "I AM" and the other ones "an invisible man" of the same sentence or the difference between those concerned letters "I AM" and other ones such as "spook", "ghost", "Hollywood movie ectoplasm" used in the same prologue to characterize the protagonist in INVISIBLE MAN, p.7. 
In clear, when referring to the philosophical statement "I think, therefore I am" which puts together two inter-related entities "I think" and "I am", it is observed that the protagonist-narrator claims and emphasizes only one entity which is "I AM": that notion of physical existence (flesh, body, fiber etc.) to which Descartes refers to as "the body" or "the latter":

so that 'I', that is to say, the mind by which I am what I am, is wholly distinct from the body, and is even more easily known than the latter ...I considered myself as having a face, hands, arms, and all that system of members composed on bones and flesh as seen in a corpse which I designated by the name of body ... By the body I understand all that which can be defined by a certain figure: something which can be confined in a certain place, and which can fill a given space in such a way that every other body will be excluded from it; which can be perceived either by touch, or by sight, or by hearing, or by taste, or by smell ... ${ }^{34}$

And, if one puts in relationship the first part of the sentence which is "I AM" and the second part which is "an invisible man" and if one comes back to the philosophical concept of existence developed by Descartes "I think, therefore I am"; one can realize that the protagonist-narrator's sentence "I AM an invisible man" means simply "I AM" BUT "an invisible man". Such a conclusion shows that there is a big contrast or ambiguity because when people take the expression "I AM", it means that the author exits and does exist. So how does it come that a person, who exists, becomes automatically invisible or "an invisible man"?

It is through this question that Ralph Ellison really sheds light metaphorically on the existentialist philosophical concept characterizing the protagonist "Invisible Man" existence and to a larger extent, the existentialist philosophical concept which characterizes all black people existence. And here resides the real philosophical concept of existence linked to the protagonist invisibility, to African Americans invisibility and at a larger point, to black people invisibility in general.

The African American (the major character) exists but at the same time, he is not visible, he is "unseen" while commonly speaking when we exist or when we "ARE" (in "I AM"), it means that we are visible or we should be visible. ${ }^{35}$ The relationship therefore shows clearly here that there is an important entity (or important value) of any human being that is denied to him (the major character) or that is absent (missing) in the common philosophical

34 https://newlearningonline.com/new-learning/chapter-7/descartes-i-think-therefore-i-am consulted on January 10th, 2020.

35 "Ellison at this point implies that if a man is invisible, it is possible that his surroundings are invisible, too" in "The Motifs of Blindness and Invisibility within the Influence of Postwar Existentialism as Reflected in Invisible Man by Ralph Ellison" by Yildiray Cevik, Athens: ATINER'S Conference Paper Series, No: LIT2012-0278, (2012), p.9. 
concept of existence stated by Descartes. In fact, the "whole essence or nature" of any human being which "consists only in thinking" is absent, missing or is denied to the African American (the major character) that is why using irony, he says later "- and I might even be said to possess a mind" simply because this entity of "thinking" is not attributed or is denied to him and at a larger sphere, is denied to all black people by white people.

The Introduction to the Science of Sociology, Park and Burgess's standard textbook for college sociology classes in the 1930s, offers this definition: "The Negro is, by natural disposition, neither an intellectual nor an idealist, like the Jew; nor a brooding introspective, like the East Indian; nor a pioneer and frontiersman, like the Anglo-Saxon. He is primarily an artist, loving life for its own sake. His métier is expression rather than action. He is, so to speak, the lady among the races" (Bloom, 2008: 14).

And it is here that one may see through the notion of invisibility and the rhetoric implied in it how two existentialist philosophical concepts are opposed:

Descartes' philosophical concept of human being existence:

1- I think, therefore I am

2- I think, therefore I am and I am a visible man because I think ("so that 'I', that is to say, the mind by which I am what I am, is wholly distinct from the body, and is even more easily known than the latter")

Ellison's philosophical concept of African American existence and black people existence:

1- I AM an invisible man- and I might even be said to possess a mind

2- I AM BUT an invisible man because it is not sure I possess a mind

3- I AM BUT I don't think so I AM an invisible man

4- I don't think BUT I AM so I AM an invisible man

5- Because I don't think I AM an invisible man

More recently the discussion of the relation between ideology and rhetoric has taken a new turn. Ideology is here foregrounded and problematized in a way that situates rhetoric within ideology, rather than ideology within rhetoric. In other words, instead of rhetoric acting as the transcendental recorder or arbiter of competing ideological claims, rhetoric is regarded as always already ideological. This position means that any examination of a rhetoric must first consider the ways its very discursive structure can be read so as to favor one version of economic, social, and political arrangement over other versions.... A rhetoric can never be innocent, can never be a disinterested arbiter of the ideological claims of others because it is always already serving certain ideological claims. (Dadey, 2006: 5-6)

At this step of the analysis, one can also argue that or interpret the expression "I AM" of the major character and namely the way it is written as a fact to claim his existence. The way he writes the "I AM" seems to be a way 
of shouting aloud his existence to the world. He is proving his existence to the world by using the capital letters "I AM" because it may be possible that he does not "really exist" and therefore he is really "an invisible man", not to himself but to other people ${ }^{36}$ namely to white people. Because he (the major character) is the one who tries to prove his own existence to the world, or to the society in which he lives:

I am invisible, understand, simply because people refuse to see me... When they approach me they see only my surroundings, themselves, or figments of their imagination -- indeed, everything and anything except me... you often doubt if you really exist. You wonder whether you aren't simply a phantom in other people's minds. Say, a figure in a nightmare which the sleeper tries with all his strength to destroy. It's when you feel like this that, out of resentment, you begin to bump people back. And, let me confess, you feel that way most of the time. You ache with the need to convince yourself that you do exist in the real world, that you're a part of all the sound and anguish, and you strike out with your fists, you curse and you swear to make them recognize you. And, alas, it's seldom successful. (Ellison, 1952:7)

When referring to Descartes and to all the demonstrations and arguments which surround his famous thesis "I think, therefore I am", we can, at this step of the analysis also deduce through a cause and effect relationship the fact that: people)

No thinking $=$ No existence $=$ invisible $=($ so invisibility for black

And this new equation may be possible for the major character who clearly says: "I am a man of substance, of flesh and bone, fiber and liquids -and I might even be said to possess a mind" (Ellison, 1952:7) because in his statement the characteristic (entity) of "thinking" (to possess a mind) is written in the infinitive form. In clear, the verb is written in the infinitive form ${ }^{37}$ and not at the first personal pronoun of the simple present tense like in the statement "I AM". So in conclusion, one can retain concerning the protagonist-narrator the following equation:

I AM38 $\{$ BUT $\}$ an invisible $\operatorname{man}^{39}=$ because NO THINKING ${ }^{40}$

36"You often doubt if you really exist. You wonder whether you aren't simply a phantom in other people's mind" in INVISIBLE MAN, P.7.

37 basic form of verb: a form of a verb with no reference to a specific tense, person, or subject.

38 "I AM" (so part of existence-physical existence).

39 "an invisible man" (so not part of visible men-not considered as an individual in/of the society).

40Because NO THINKING (so not human being as well as the other human beings when referring to Descartes' philosophy). 
What about the first entity or the important value ("I think") of human being evoked by Descartes and what is the relationship between this important entity and the other one ("I AM") mentioned by the narrator? To respond to this question, he says: "I am a man of substance, of flesh and bone, fiber and liquids -- and I might even be said to possess a mind."

The fact to claim his existence through the words "I AM" and to say later the contrary in the same sentence through the words "an invisible man" is not due to the fact that he does not exist. But rather, it is due to the fact that for white people, his existence is merely an invisible existence ${ }^{41}$. And this fact automatically lets him be "an invisible man". He becomes "an invisible man" because the first important quality which makes him a human being or a human existing and visible: the quality "I think" (thinking) in the sentence "I think, therefore I am" seems not to be part of our protagonist-narrator (or part of black people) as for white people conception or perception about him "I am invisible, understand, simply because people refuse to see me"... "When they approach me they see only my surroundings, themselves, or figments of their imagination-indeed, everything and anything except me." (Ellison, 1952:7)

That is why, when asked after this particular and important entity or value, he says clearly: " - and I might even be said to possess a mind" but not "I possess a mind" 42 as he used to claim or say clearly "I AM" both in the typography ${ }^{43}$ and in the meaning. ${ }^{44}$

The literary construction (syntax and semantics) that he uses to refer to that other entity of human being which is "thinking" and which is the most important in Descartes philosophical concept shows confusion and an ambiguous idea. In one case, he is sure of something but in the other case he is not sure, or at least, he leaves this other important value to the appreciation of other people and namely to the appreciation of white people. He prefers that other people claim it for him, or state it for him as if there is a kind of irresponsibility and a kind of doubt or uncertainty.

Ellison and Momaday explore how different rhetorics produce distinct, often conflicting realities, and how alternative rhetorical traditions might assist marginalized people to redefine their identities and reconfigure the social and political contexts in which they live. At the same time, the novels, written and published during periods of increasing racial tension in the United States, are themselves rhetorical products that influence their readers.(Dadey, 2006: 6-7)

41 "I am invisible, understand, simply because people refuse to see me" in INVISIBLE MAN, P.7.

42The value which determines the thinking (or the use of thinking), the value which permits any Human being to think, to reflect, to create, etc.

43 Look at the printed matter: the appearance of printed words on the page.

44 State his existence, state his physical existence. 
Quite different from the conventional philosophical concept of human being existence in Descartes' analysis, Ralph Ellison gives us another philosophical concept of black human being existence through the protagonist-narrator "Invisible Man" which is:

"I AM" and "I might even be said to possess a mind"

or rather

"I AM" so "I might even be said to possess a mind"

or rather

"I AM" then "I might even be said to possess a mind"

The characteristic of mind, the most important for human beings according to Descartes' concept and through which a person is an existing person who is considered, seen, taken into account among people in his society (or in the society) as an equal human being is not seen in our protagonistnarrator "Invisible Man" and in African American. That is why he says: "when they approach me they see only my surroundings — indeed, everything and anything except me".

\section{Conclusion}

By definition, the prologue means the introduction but also the beginning. And in the novel INVISIBLE MAN by using the prologue to introduce us to the central and important notion of invisibility and namely by introducing us to black people invisibility, Ralph Ellison wants metaphorically speaking to tell us that the very beginning of all the problems of black people or the prologue of the plight of black people in their existence is their invisibility ("my invisibility" ${ }^{45}$ ). That invisibility they have through the perception or the inner eyes of white people. ${ }^{46}$ So the prologue of their problems in their existence is really the problem of their invisibility. All people are visible or normally speaking all people should be visible because they are endowed and characterized by the thesis "I think, therefore I am" or "I think, therefore I am/exist". But as far as black people are concerned, and in the perception of white people, they are endowed and characterized by the thesis "I AM / EXIST" - "and I might even be said to possess a mind" or "I AM a man of substance, of flesh and bone, fiber and liquids -- and I might even be said to possess a mind." (Ellison, 1952:7) On the basis of such a thesis, white people consider black people as invisible because for white people "they are" [black people are], "they do exist" [black people exist], but they don't possess

45 Expression used by the protagonist-narrator at the first line of the second paragraph in the prologue.

46 "That invisibility to which I refer occurs because of a peculiar disposition of the eyes of those with whom I come in contact. A matter of the construction of their inner eyes, those eyes with which they look through their physical eyes upon reality." in INVISIBLE MAN, p.7. 
"a mind", they don't possess "thinking". And due to the fact that for white people the entity "I think" or "I mind" is prior to the entity "I am/exist" so black people are not visible, they are rather invisible ${ }^{47}$. That is why Ralph Ellison introduces his novel by the sentence "I AM an invisible man" meaning "I AM [BUT] an invisible man" meaning "I exist [BUT] an invisible man" meaning "I don't think", "I don't possess a mind" according to white people. Thanks to such a prejudice it is easy to determine the existentialist philosophical concept which characterizes black people invisibility through the inner eyes of white people. That is why this new concept which foreshadows the invisibility of black people is the contrary of the universal concept promoted by Descartes through his thesis "I think, therefore, I am".

One final point: The narrator is an Afro-American. Part of the reason he's invisible is that Ellison feels white people do not see black people. Much of what he suffers comes at the hands of white people and those blacks who work for white people. From this point of view the narrator may be interpreted as a symbol for the black person in America. (Abbott, 1985: 24)

Due to the relevance of the theme of invisibility debated and regarding the stylistic aspects mentioned (typography), this review at the end puts in question the revision of the sentence "I AM an invisible man" 48 into the sentence "I am an invisible man" ${ }^{49}$ and its usefulness. When we observe through this analysis that the written form of the sentence "I AM an invisible man" 50 of the old and first edition better fits both in the form and in the content the notion of invisibility linked to black people existence that Ellison is taking about.

At some levels, we can admit that the written form of the sentence "I $\mathrm{AM}$ an invisible man"51 is suitable to convey the message the author wants to convey through the notion of invisibility which characterizes black people in the white American society while they do exist. Even if the analysis is the same in terms of value and message conveying about the notion of invisibility, it is important to precise that the written form or the typography of the sentence "I AM an invisible man" conveys better the existentialist philosophical concept about black people invisibility both in terms of form (capital letters)

47 "I am invisible, understand, simply because people refuse to see me... When they approach me they see only my surroundings, themselves, or figments of their imagination -- indeed, everything and anything except me." in INVISIBLE MAN, p.7.

48 An old Edition of the corpus we used for our paper published by Penguin Modern Classics, Penguin Books Ltd, First published in the USA 1952, published in Penguin Books 1965, Reprinted 1969-1984, Copyright-1947-1948-1952 by Ralph Ellison.

49 A very recent Edition of the same corpus (the Second Vintage International Edition of March 1995, Copyright renewed 1980 by The Ralph and Fanny Ellison Charitable Trust or on that of Vintage Book Edition).

50 The Edition of the corpus we used for our paper.

51 The Edition of the corpus we used for our paper. 
and in terms of semantics. That is why we may question the revision of the sentence "I AM an invisible man" into the sentence "I am an invisible man" here at the end of our analysis.

\section{References:}

1. Abbott, Anthony S. (1985). Ralph Ellison's The Invisible MAN. Copyright by Barron's Educational Series, Inc.

2. Asante, Molefi Kete. (1998). The Afrocentric Idea. Revised and Expanded Edition. Philadelphia: Temple UP.

3. Backry, Patrick. (1996). Les figures de styles. Berlin, Paris.

4. Barry, Peter. (1995). Beginning theory, An introduction to literary and cultural theory. Second edition. Peter Barry.

5. Berlin, James. (1998). "Rhetoric and Ideology in the Writing Class." College English 50.5: 477-94.

6. Betts, Raymond F. (1971). The Ideology of Blackness. Lexington, Massachusetts: D.C. Heath and Company.

7. Beugré, Stéphane. (2014). La Perception des Blancs dans la Poésie de Claude McKay et Langston Hughes. Bouake: Université Alassane Ouattara.

8. Bloom, Harold. (2008). Ralph Ellison's Invisible Man. Bloom's Guides. Infobase Publishing.

9. Bronz, Stephen H. (1964). Roots of Negro Racial Consciousness. New York: Libra.

10. Burns, Sir A. (1949). Le préjugé de race et de couleur. Paris: Payot.

11. Cevik, Yildiray. (2012). "The Motifs of Blindness and Invisibility within the Influence of Postwar Existentialism as Reflected in Invisible Man by Ralph Ellison.” Athens: Atiner's Conference Paper Series, No: LIT2012-0278.

12. Chadwick, Charles. (1971). Symbolism. London: Methuen.

13. Dadey, Bruce. (2006). Rhetorics Rising: The Recovery of Rhetorical Traditions in Ralph Ellison's Invisible Man and N. Scott Momaday's House Made of Dawn (Thesis). Ontario, Canada.

14. D. Hill, Michael and M. Hill, Lena. (2008). Ralph Ellison's Invisible Man A Reference Guide. Greenwood Press: Westport, Connecticut, London. Greenwood Guides to Multicultural Literature.

15. Descartes, René. (1637). Discourse on the Method. Oxford World's Classics.

16. Du Bois, W. E. B. (1903). The Souls of Black Folk. Essays and Sketches. New York: NAL, (1969): 45-53.

17. Ellison, Ralph. (1952). Invisible Man. New York, USA: Penguin Modern Classics.

18. Gadamer, Hans-Georg. (1982, traduction par Marianna Simon). L'art 
de comprendre. Herméneutique et tradition philosophique. Paris : Aubier Montaigne.

19. Glenn, Cheryl. (1997). Rhetoric Retold: Regendering the Tradition from Antiquity Through the Renaissance. Carbondale: Southern Illinois UP.

20. Grondin, Jean. (1993). L'universalité de l'herméneutique. Paris, Epiméthée, P.U.F.

21. Grondin, Jean. (2006). L'herméneutique. PUF, "Que sais-je ?".

22. https://www.penguin.co.uk/books/256/25629/invisibleman/9780241970560.html consulted on January 10th, 2020.

23. https://1000wordphilosophy.com/2018/11/26/descartes-i-thinktherefore-i-am/ consulted on January 10th, 2020.

24. https://newlearningonline.com/new-learning/chapter-7/descartes-ithink-therefore-i-am consulted on January 10th, 2020.

25. https://1000wordphilosophy.com/2018/11/26/descartes-i-thinktherefore-i-am/ consulted on January 10th, 2020.

26. https://shodhganga.inflibnet.ac.in/bitstream/10603/64079/7/07_chapt er\%201.pdf / CHAPTER ONE / ASSERTIVE BLACK POETS/ consulted on January 10th, 2020.

27. Juozapaityte, R. (2001). 'Quest for visibility in Ralph Ellison's Novel Invisible Man.' Literature, 43 (4), 131-141.

28. Kent, George. (Mars 1992). Blackness and the Adventure of Western Culture. Third World Press, U.S.

29. Kerry, McSweeney. (1988). Invisible Man: Race and identity. A student's companion to the novel. Boston.

30. Lyne, William. (1992). 'The Signifying Modernist: Ralph Ellison and the Limits of the Double Consciousness'. Modern Language Association of America. Proceedings (PMLA) 107 (March 1992) : 319-30.

31. Merleau-Ponty, Maurice. (1945). Phénoménologie de la Perception. Paris : Gallimard.

32. Merleau-Ponty, Maurice. (1964). Le Visible et l'Invisible. Paris : Gallimard.

33. Microsoft ${ }^{\circledR}$ Encarta ${ }^{\circledR}$ (2009). ㄷ 1993-2008 Microsoft Corporation. Tous droits réservés.

34. O'Meally, Robert G. (1980). The Craft of Ralph Ellison. Harvard University Press.

35. O'Meally, Robert G. (1988). New Essays on "Invisible Man" (the American Novel). Cambridge University Press.

36. P. L., Van Den Berghe. (1967). Race and Racism. New York: John Wiley and Sons INC. 